\title{
Managing Sustainable Development of Socio-Economic Systems
}

\author{
Olga Viktorovna Lenkova ${ }^{1}$, Veronika Vasilyevna Efremova ${ }^{1}$, Sergej Vladimirovich Postarnak ${ }^{1}$, Ruslan Olegovich \\ Pogrebnoj $^{1}$, Sergej Igorevich Skipin ${ }^{1} \&$ Ajdarbek Orazaevich Erezhepov ${ }^{1}$ \\ ${ }^{1}$ Tyumen State Oil and Gas University, Tyumen, Russian Federation \\ Correspondence: Olga Viktorovna Lenkova, Tyumen State Oil and Gas University, 625000 Tyumen, \\ Volodarskogo Street 38, Russian Federation. E-mail: olga_lenkova@mail.ru
}

\author{
Received: July 14, 2014 Accepted: July 30, 2014 Online Published: November 27, 2014 \\ doi:10.5539/ass.v10n24p63 URL: http://dx.doi.org/10.5539/ass.v10n24p63
}

\begin{abstract}
Nowadays, the concept of sustainable development permeates the entire economy, affecting the development of certain commercial structures, local areas and even countries. As mentioned above, the stability of the whole system is derived from the stability of its constituent elements. Although, in practice, a direct relationship between these phenomena do not exist. Identification of these mechanisms will form a model of sustainable development management of socio-economic system based on the balanced development of its individual elements. This project is aimed at solving the problem of finding a balance between the need to develop socio-economic systems in modern conditions and sustainability of their operation. Crises of recent years have actualized questions the sustainability of commercial organizations, as showed no willingness of individual companies to major changes in the external environment, as well as proven strategies unsustainability developed earlier in their development. Meanwhile, in terms of increased competition in some markets and in some regions, as well as in terms of accelerating changes in the environment of non-standard search ("breakthrough") strategic decisions, radical transformation of existing ideas about the technologies and the possible trajectories of development is often the deciding factor and the pledge successful companies in the future. Objects of research-oil and gas companies and local territory of the Russian Federation. Subject of research-theoretical and methodological, organizational and practical aspects of sustainable development of the energy profile of Russian and local areas.
\end{abstract}

Keywords: sustainable development, socio-economic systems, local area, oil and gas companies, economic sustainability, environmental sustainability, social sustainability

\section{Introduction}

Nowadays many scientists point out three basic global humanity problems: 1) technological and economical implying the exhaustion of natural resources. 2) Ecological; biological balance between humanity and nature in global pollution condition, 3) socio-political problem. Balance violations can provoke critical and even catastrophic consequences that violate separate systems (socio-economic and ecological). It appears to be possible to use the conception of stable development, which implies that tripersonality of economic social and ecological stability is used to control those aspects. This conception was invented in early 70's. Stable development is a process that includes natural resources exploitation, courses of investments, orientation of scientific and technical development, evolution of personality and institutional changes that comport with each other and consolidate present and future potential of satisfying human wants and aspirations.

In 2002 Russian State Duma created the Stable Development Committee that published ad act entitled "Fundamental development strategy of Russian Federation". This considers different aspects of stability foreign policy aspect, ecological, economic, social and territorial aspects. The act indicates the importance of science and high tech as instruments of controlling the development stability. It also lists the way of realizing the development strategy, lists the hotlist of stable development indices. However, these aspects were presents only to be examined from the macroeconomic point of view. Meso and microlevel implementation arrangements are not suggested in this act.

At the same time, using system approach and decomposing socio-economical systems, it is logical to suggest that the basis of system stability will be defined by stability of its separate elements and communication quality of these elements. In that case it is logical to confirm that development stability of humanity depends on stability 
of separate countries and interactions between those countries. Steadiness of a single country depends on the stability of its territorial formations. Regional stability, at the same time, depends on stability of business entities of a specific region. At the same time business entities are not interested in making managerial decisions not only from the economical effectiveness point of view, but also considering social and ecological consequences. Many companies and organizations realize the concept of stable development fragmentarily (Plenkina \& Osinovskaya, 2012).

If we examine this problem from the scientific point of view, it is impossible not to mention contradictions between definitions of "stability" and "development". "Stability" implies balance and "development" on the other hand is possible only being out of balance. Difficulty in solving the stated problem is increased with raw theoretical and methodical basics of stable development management. It appears in necessity in changing present conceptual basics (terminology, typological qualities etc.), using complex approach to choosing indicative basics of measuring stability and systematic approach to forming ways of managing stability on different levels of system hierarchy. So nowadays, the concept of stable development enters economics, raising questions about development of separate business corporations, territories and even countries. As it was mentioned earlier, stability of an entire system is a result of stability of the elements of the system. However, practical work shows us that there are no direct relations between these facts (Belonozhko \& Silin, 2013). Discovering such relations can help create a management model for stable development of socio-economical system on a basis of balanced development of separate elements of this system.

This project is directed to solving the problem of searching for the balance between the needs of socio-economical systems development in present conditions and guarantying functional stability of those systems.

The latest crises actualized the questions of functional stability of proprietary organizations, because it showed unpreparedness of certain organizations to serious global changes and it proved inviability of old development strategies (Gazeev, 2013). Meanwhile in the condition of growing competition in certain markets and in certain regions and also in condition of accrual changes in external environment the search for non-typical strategic decisions and transformation of existing ideas about technologies and vectors of possible development often become a conclusive factor and success pawning for the company in the long term.

Nowadays oil and gas business is the main tax source for budgets of different levels, it is hard to overestimate its significance for Russian economics. Along with that, a considerable amount of functional problems of oil and gas business entities stay unsolved (Lenkova \& Osinovskaya, 2013). In particular, aggravation of sources of raw materials which needs more and more expenses for maintenance and hydrocarbon raw materials production, along with high ecological load on environment and growing social problems inside the companies need transformation of management approaches. It becomes difficult to make decisions basing it only on economic hallmarks, taking into account the high level of social responsibility in oil and gas companies (Simonov, 2013). E.g. in case of high supplies exhaustion and low (and even negative) profitability of oil and gas production it can be difficult to realize strategies of reduction or liquidation due to social infrastructure existing on this certain territory(Chizhevskaya, 2013). This also explains problems with using effective ways of outsourcing for oil and gas companies on certain territories.

In these circumstances, some oil and gas business entities keep on functioning with these unprofitable assets in corporate portfolio. In some cases, business entities try to create rotation bases in present cities in order to overcome these problems. However, there is a need for changing general management paradigm, which assumes a systematic solution for the designated problem, searching for compromise between aims that confront with each other, and not the fragmental realization of management actions (Deberdieva, 2012). These are usually economic ecological and social reference points. Nowadays there is no unified way of making a comprehensively balanced decision about further development of business entities.

Modern territorial economies are dynamic systems that are always influenced by market factors, and because of that influence structural changes are made and these changes demand adaptation to present conditions from the industrial sector, the conditions which make planning a central structural unit of management (Deberdieva \& Lenkova, 2011). The last point is caused by the fact that structural reorganization is not a stable process, it depends on current situation and sometimes it does not correspond with the long-term development strategy of regions and even the state.

Strategic analysis of internal and external environment in any socio-economic system is a benchmark to creating the development programs, because it allows estimating external dangers and possibilities according to its vices and recommendations (Russian Energy, 2008). In unstable environmental conditions, corrections to organization 
orientations and long-term programs to liquidate the strategic breaches with improving the use of potential have to be applied. Therefore, the economic unit effectiveness depends on correct and rational decisions, which, on the other hand, depend on sharpness adequacy and timeliness of resources potential diagnostics results (Silin \& Belonozhko, 2014).

Nowadays the problem of stable development of regions of different levels becomes actual. The problems of raising the effectiveness of use of resource potential in specific territory along with developing social and economic infrastructure.

The analysis of modern scientific researches on the problem of choosing the correct and perspective ways and instruments of developing the business entities in oil and gas production allows making a conclusion that the present theoretical and methodological basis needs to be adapted and transformed for the certain research object (Deberdieva, 2012; Osinovskaya, 2012).

The object of the research-oil and gas producing companies and local territories of Russian Federation.

The subject of the research-theoretical and methodical, organizational and practical aspects of managing stable development Russian oil and gas companies and local territories.

The resolution of this research can be applied to Russian oil and gas companies and local territories. It can be the basis for formulating the fundamental concepts of stable development for its further use outside the branch and levels of the object of the research.

\section{Method}

The goal of this project is developing theoretical and methodical basics of managing the stable development of oil and gas companies and local territories. To achieve the goal, the following problems have to be solved:

1) Prove the essence of development stability of socio-economic system on different hierarchy levels and also determine its typological impletion and its components that either help or hinder the process of development;

2) Sum theoretical and practical experience in the field of stable development up, find and systemize conceptual aspects of the new development paradigm and apply it to actual problems of oil and gas companies and local territories;

3) Create a methodical adaptive approach to complex analysis of business entities stability based on indicative evaluation of separate stability elements;

4) Determine the indicators the show the status and level of use of the resources potential, adapt it to the research objects, describe the effectiveness of using resource, industrial and financial potentials of oil and gas companies and local territories;

5) Examine, systematize, pick and adapt theoretical and methodological opportunities from other fields of knowledge that research the definition "stability".

Create a stable development management mechanism for socio-economic systems.

Many Russian and foreign scientists has studied this problem. Formulating analytic approaches to estimating the balance of stability is the topic of studies of the following authors: A. Marshal, L. Valras, V. Pareto, O. Kurno, K. Arrow, G. Debreu, L. McKenzie, D. Gale, O. Vange, V.M. Polterovich, A. Wald, J. Kanes, J. Hicks, E. Altman. M. Abriutinoi., V. Kovalev, d Volozhanin, A. Sheremet. Next authors studied the methods of systematic analysis: N. Wiener, L. Zade, E. Lorents, N. Moiseev, A. Bogdanov, L. Kontarovich, V. Leontiev, V. Nemchinov, G, Hacken, I. Prigozhin, Yu. Urmancev, E. Liyv, K Shannon, S. Young, F. Roberts. In Russia this aspects started to be discussed after 01/04/1996 Presidential act №440 "Concept of Russian Federation moving to stable development". Specific development questions were researched by T. Arzumanova, O. Baskakova, O. Volkov, V. Gorfinkel, E. Grazhdankina, V. Gribov, V. Gruzinov, V. Kuzmenko, V. Zhideleva, Yu. Kantein, N. Zaycev, A. Laickiy, N. Lisitsin, K. Raitskiy, V. Savickiy. N. Safronov, V. Semenov, I. Baev, C. Terehova, I. Sergeev, V. Sklyarenko, V. Prudnikov, G. Susha, V. Titov. Along with that some other stability were researched by M. Alekseeva, A. Brentz, V. Tishenko, Yu. Malishev, L. Vladimirova, V. Goremikin, E. Bugulov, A. Bogomolov. A. Ilyin.

A significant job in the field of developing theoretical and methodical aspects of oil and gas organization economic stability problem was done by V. Alekperov, A. Arbatov, V. Bogdanov, E. Dokuchaev, A. Ilyinskikh, A. Konoplyanik, E. Korzun, V. Kryukov, A. Perchik, A. Kharitonov, V. Plenkina, N. Volinskaya, I. Andronova, L. Guzhnovskiy, M. Gazeev. Their researches proved some oil and gas company stability management aspects. 
Along with this there are some aspects that yet has to be proved, aspects of factors and conditions which form the stability and also the methods of estimating it.

Russian scientists who researched the stable development of local territories are T. Avdeev, I. Blam, A. Voronin, M. Ganapolskiy, S. Gaponova, A. Tatarkin,V. Danilov-Danilyan, V. Koptyuga, V. Levashov, V. Matrosov, N. Moiseeva, A. Orlov, M. Palkina, K. Papenov, A. Penyugalova, M, Tereshina, A. Ursula, N. Fedorenko. The following scientists pay significant attention to the problem of creating the system of indicators for estimating the regional stable development: G. Mekush, C. Bobilev, N. Sorokina, T. Kotova, E. Markelova, N. Miroshnik, V. Bulatov, N. Igenbaev, I. Rubanov, V. Tikunov, A. Leontieva. Special attention must be payed to the researches of foreign scientists-H. Daily, J. Farley, J.G. Spetsh, J. Ericsson, R. Heinberg.

New scientific field-ecological economic-which is based on concept of stable development is introduced in researches of P. Soderbaum, H. Daily, R. Constanca. Territorial ecologization problems are introduced in the works of O. Bashorina, I. Temkina, C. Bobileva, A. Hodzhaeva, T. Doroboliuk, B. Kalachevskogo, N. Zhuravel, M. Kalinnikova, O. Litovka, L. Dedov, K. Pavlov, M. Fedorov, T. Lyubavina, O. Malikova, V. Muratkina, C. Prokopenkov, B. Semenenko, N. Mishenina. Ecologization mechanism is introduced by A. Dengin, A. Borodin, I. Maiburova, O. Burmatova, N. Guseva, A. Egorov, M. Zershikova, S. Lutkovskaya.

Ecological, environmental safety, and rational raw material use are researched by V. Protasov, N. Reimers, A. Barlukov, V. Danilov-Danilyan, V. Bganba-Cerera. N. Vishnevskaya, E. Girysova, V. Lopatina, E. Magaril, M. Ignatieva, Ya. Yandiganov.

\section{General science competitors.}

1) SIT Graduate Institute Brattleboro, Vermont, USA

2) International Academy of the University of London

3) Ben-Gurion University of the Negev, Israel

4) Office of the Auditor General of Canada

5) The Columbia University Post baccalaureate

6) American University of Central Asia

7) Norwegian University of Life Sciences

8) International Centre for Interdisciplinary Research in Law (ICIRL), Canada

9) Laurentian University Centre for Research in Social Justice and Policy (CRSJP), Canada

10) Laurentian University Ontario International Development Agency (OIDA), Canada

Also the research is being provided by following social organizations:

1) The UN Stable Development Commission

2) IEA

3) Organization for Economic Co-operation and Development

4) EA

5) European Commission.

Scientific novelty of the goal of the research. The prove of the attainability of the solution of the problem

Scientific novelty of the research is the proving the methods of solving an important problem of searching for the balance between the need for developing of oil and gas business entities and local territories in present conditions and securing functioning of the entities at the same time in developing theory and methodology of stable development management in unstable environmental conditions (Deberdieva, 2014; Karnaukhov, 2010). The most significant results of the research will probably be:

1) Developing definitions and categories for stable development management of socio-economic systems

2) Formulating structural-logical model of stable socio-economical system with emphasizing the main elements, describing elemental correlations, which determine the development stability

3) Proving the indication system that allows making complex estimation of economic ecological and social stability of oil and gas organizations and local territories. Developing recommendations for using the offered indicators for preparing and making the decisions on different levels of management hierarchy. 
4) Systematizing the management tools for using in different situations that disturb the socio-economic systems stability. Developing the present tools to manage the stable development, based on adapted theory and methodic from other fields of science

Creating recommendations on raising the motivation of socio-economic system managers with the realizing the concept for their stable development taking into account economic social and ecological effectiveness (Deberdieva, 2012; Plenkina, 2013).

\section{Results.}

Systematic, synergetic, worth approaches, dialectic epistemology, economic-mathematical and logical-probabilistic simulations, financial, management and strategic analysis, logical deduction and induction, reduction, classification and cognitive structuring are the methodological basis of this research (Deberdieva, 2012).

Providing theoretical and methodological aspects, conclusion and suggestion reasoning will be based on using systematic-functional approach to this problem (Deberdieva, 2012; Osinovskaya, 2014). Depending on the goals, the following methods and ways of researching will be used: abstract-logical, analytical, economic-statistical, expert method, monographic method, balancing method.

Providing theoretical and methodological aspects, conclusion and suggestion reasoning will be based on using systematic-functional approach to this problem. Depending on the goals, the following methods and ways of researching will be used: abstract-logical, analytical, economic-statistical, expert method, monographic method, balancing method (Plenkina, 2013).

The most significant results to be obtained in the work, and their scientific novelty presumably would be as follows:

1) Develop conceptual and categorical apparatus managing sustainable development of socio-economic systems.

2) Formation of structural logic model of sustainable development of socio-economic systems with the release of the key elements that describe the relationship between them and identifying the factors that determine sustainability.

3) Justification indicator system, which allows a comprehensive assessment of economic, environmental and social sustainability of oil and gas companies and local areas. Making recommendations on the use of the proposed indicators in the preparation and decision-making at different levels of the management hierarchy.

4) Systematization of management tools for use in different situations violations sustainability of socio-economic systems. Development of existing instruments stability control by adapting the relevant theoretical and methodological aspects of the other branches of science.

5) Development of recommendations for increased interest (motivation) of the subjects of socio-economic systems in implementing the concept of sustainable development, taking into account economic, environmental and social efficiency.

\section{Discussion}

There are also a point of view, according to which at present do not need to pay much attention to the stability of the existing oil and gas structures, and focuses on the development of alternative energy. Give reason for such statements constraints (non-renewable) hydrocarbons and progressive appreciation of its production. The urgency to find alternative energy resources is indisputable. However, there is development, and including local scientists, for doubting the non-renewable oil and gas reserves. And the cost of development of these resources, as noted above, the serious influence current policy of the state. In addition, there is a question about the future of the currently existing assets in the oil and gas sector and infrastructure (including social) accompanying this business. We would like to focus on the role of government in improving the sustainability of oil and gas companies. You may disagree, but we believe that oil and gas companies are now the tool of the multiple functions of the state. As previously mentioned, they bring a significant amount of money to the treasury through tax deductions. The tax burden imposed by the state on these organizations is considerable. This is demonstrated by the fact that the cost structure of oil production is about $70 \%$ tax on mining. And when you consider all of the tax payments committed by vertically integrated oil and gas companies across the value chain of the final value, the values are obtained quite impressive. At the same irrational and distribution of the tax burden on the parts of the technological chain-the main part of it falls on the most technologically advanced and expensive units-mining and processing. A similar situation is observed in relation to exports of oil and oil products, where a significant proportion of the value added by the state withdraws export duties. 
It is noteworthy that with all this trying to become more active government intervention in the regulation of the prices of petroleum products, are increasingly published information about the next "incrimination" oil companies colluding or otherwise violating antitrust laws. So much attention to the state of pricing in the oil market is clear and easily understandable, especially for gasoline market, which are the main energy sources, rising which leads to the acceleration of "fuel" of inflation. However, knowing the laws of pricing, it should still indicate that the lower limit is determined by the price level of production costs, which, as already noted, is also of considerable influence state. In this situation, there is a certain paradox. On the one hand, the government uses the oil and gas companies as a major "donors" of the Russian economy by imposing their significant tax burden on the entire production chain. On the other hand, the government attempts to regulate the value and volume of sales of these companies to end markets (especially in certain market segments-the army, the Northern delivery, seeding, etc.).In all of this today updated implementation within oil and gas entities triune concept of sustainable development, according to which the company should be guided not only economic but also environmental and social performance criteria. That is part of the functions that are often alien to the commercial entities from other activities, and is traditionally considered to be public, in this case, the "shifted" to the oil and gas companies.

In these conditions, as we see it, perhaps, a few scenarios (including hypothetical choices):1. Weakening of "control" of the state and leaving most of the existing tax deductions for companies to finance their environmental and social programs, raise the level of innovativeness of the projects, cost reduction target of production, etc. 2. "Nationalization" of the oil and gas business, which involves the abolition of private ownership of oil and gas assets and the establishment of state ownership in the industry.3. Preservation of the existing situation.

As we see it, most likely will continue to implement the third option, under which will further worsen the situation with physical and obsolescence of technologies and assets in the oil and gas field on a background of progressive appreciation of the target companies' products in all parts of the technological chain.

\section{Conclusion}

These scientific results can serve as a basis for adjusting the individual legal acts regulating the issues of sustainable development of socio-economic systems. Also with the use of research results possible formation of guidance documents for managing sustainable development businesses. Moreover, the solution of applied scientific problems in relation to domestic companies to oil and gas and local areas may serve as a basis for the formation of the fundamentals of sustainable development for their subsequent widespread use outside the industry and research facilities tier accessories.

\section{References}

Belonozhko, M. L., \& Silin, A. N. (2013). Russian North: Change of Social Situation. Middle-East Journal of Scientific Research, 16(2), 150-155.

Chizhevskaya et al. (2013). Regional Branding as Factor of Achievement of Competitiveness of the Territory. World Applied Sciences Journal, 28(2), 185-188.

Deberdieva et al. (2012a). Sustainable development of oil and gas companies: Conditions and prospects. Oil and Gas business, 11, 11-13.

Deberdieva et al. (2012b). The implementation of the concept of sustainable development in the oil and gas companies Economic and legal management procedures of overcoming the social crisis/Materials digest of the XXVII International Scientific and Practical Conference and the II stage of Research Analytics Championship in culturology, architecture, art history and philosophical sciences (London, June 28-15, 2012).

Deberdieva, E. M. (2012a). Benchmark oil companies: Theoretical and methodological foundations. Saarbrucken: LAP LAMBERT Academic Publishing GmbH \& Co. KG.

Deberdieva, E. M. (2012b). In S. S. Stuttgart (Ed.), Cost-effectiveness of organizational changes in the oil production/Economic potential and perspectives of Europe (pp. 209-229, 302). Russia and CIS states, ORT Publishing, 2012.

Deberdieva, E. M. (2012c). The concept of life cycle implementation in creating the strategy of oil company development//Life quality of subjects of modern education-2012: The almanac/under the editorship of $N$. Golikov, E. Mironova-Almaty: «Tsennye bumagi» publishing house, 2012 (pp. 49-53).

Deberdieva, E. M. (2014). Production operation management of the oil-producing unit. Life Science Journal, 11(9), 381-384. 
Deberdieva, E. M., \& Lenkova, O. V. (2011). Corporate strategy development oil and gas company (p. 168). Novosibirsk: IEIE SB RAS, 2011.

Gazeev et al. (2012). Implementation of the Life Cycle Concept in Strategy Development of Oil Company. World Applied Sciences Journal, 24(5), 644-648.

Karnaukhov, M. N. (2010). Methodical bases of structural transformation of oil and gas companies. Ekaterinburg: Institute of Economics, Ural Branch of Russian Academy of Sciences, 66.

Lenkova, O. V., \& Osinovskaya, I. V. (2013). Implementation of the concept of sustainable development in Russian oil and gas companies. Middle East Journal of Scientific Research, 15(4), 482-486.

Osinovskaya et al. (2014). Energy Security in Russia: Problems and Solutions. Middle-East Journal of Scientific Research, 21(1), 144-147.

Osinovskaya, I. V. (2012). Sustainable development of the oil and gas companies: Conditions and prospects. Oil, gas and business, 11 .

Plenkina et al. (2013a). Development of managerial decisions in the oil and gas structures (p. 92). Germany, Saarbrucken: LAP LAMBERT Academic Publishing GmbH \& Co. KG.

Plenkina et al. (2013b). Restructuring of Businesses of Oil and Gas Industry as a Tool to Increase Competitiveness of a Region. World Applied Sciences Journal, 25(7), 1027-1030.

Plenkina, V., \& Osinovskaya, I. (2012). Efficiency planning of production potential of Russian oil and gas structures. In S. S. Stuttgart (Ed.), Economic potential and perspectives of Europe (pp. 98-111). Russia and CIS states ORT Publishing.

Russian Energy (1920-2020). (2008). Energy policy at the turn of the century (p. 1032). M.: ID Energy.

Silin, A. N., \& Belonozhko, M. L. (2014). Environmental Situation and Conditions for Traditional Lifestyles of Indigenous Communities in the West Siberian North. Middle-East Journal of Scientific Research, 21(1).

Simonov et al. (2014). Development of social entrepreneurship on a given territory. Life Science Journal, 11(7s), 314-317.

\section{Copyrights}

Copyright for this article is retained by the author(s), with first publication rights granted to the journal.

This is an open-access article distributed under the terms and conditions of the Creative Commons Attribution license (http://creativecommons.org/licenses/by/3.0/). 